UDC $330.34 ; 65.016$

DOI: https://doi.org/10.37320/2415-3583/14.11

Plyaskina Alona

Candidate of Economic Sciences, Senior Lecturer at the Department of External Economic Activity, Kherson National Technical University ORCID: https://orcid.org/0000-0003-3680-162X

\title{
FORMATION OF BUSINESS DEVELOPMENT STRATEGY ON THE BASIS OF THE ENTERPRISE INTEGRATION MECHANISMS
}

Scientific approaches in relation to a structure and forming of business development strategy of the enterprise in accordance with its aims and possibilities are explored and systematized. The specific of business development strategy of enterprise to the mechanisms of enterprise integration is analyzed and justified. Main tasks, which have to be decided in the process of forming the business development strategy, are also defined in this article. Approaches to interpreting the strategy of the enterprise development are discussed in the article. It is devoted to the components of business strategy of the enterprise development. It is proved that business strategy of the enterprise development on the strategic targets of enterprise development. The results of the conducted research can be used by managers of enterprises for the choice of the reasonable development strategy and strengthening competitive positions of the enterprises in the market.

Key words: development, enterprise development, business development strategy, transformation, factors, integration.

JEL classification: M21, O12

Problem statement. At the current stage of international economic relations development, globalization processes have embraced the entire world market of goods and services, which has led to a continuous increase in the integration of commodity producers and enterprises from different countries, the need to form a business strategy for the enterprise development. The main problem of enterprises business development, despite the presence of intellectual and resource potential, is the lack of a mechanism that could combine existing resources and concentrate them on the most promising trade and economic areas. Therefore, the purposeful formation of the business activity of an enterprise is the basis for the development in the economic system.

Recent research and publications. There are many works of domestic and foreign scientists devoted to the research of business strategy of the enterprise development. Among them the works of Ansoff I., Beltyukov E.A., Bzhuska J., Gorelov D.O., Zavidna L.D., Kalinichenko Yu., Kravchenko O.V., Karloff B., Melnik L., Nekrasov L.A., Omaye K., Redchenko K.I., Saenko M.G., Thompson A.A., Tyukha I.V. can be mentioned.

Materials and results. An important aspect of managing the activities of enterprises is the assessment of many factors that affect the management of the business of an enterprise in the international trade. The set of factors that affect the nature and characteristics of business management of an enterprise in international trade can be divided into two groups: external and internal (Figure 1).

In its turn, external factors are divided into global, national and subjective. The consequence of the analysis of the influence of external factors is the diagnosis of the environment for the development of the enterprise, internal factors, and the assessment of its potential.

A company that gives preference to innovative mechanisms for its economic development is based on a flexible concept. These mechanisms include the cluster model. The emergence of new and support for existing cluster structures can be the key to the progressive movement of each territorial entity.

Consequently, the ability of an enterprise to innovate is its innovative potential, one of the effective mechanisms, the increase of which we witness in the unification of efforts of groups of enterprises, i.e. clustering [1, p. 22]. Cluster enterprises are distinguished by "high" innovation $[1$, p. 18]. The central feature of clusters is that all subjects of the global market function as "players"of a common network (structure), not alone.

The proliferation of methods of multivariate analysis as a toolkit for effective management reveals ample opportunities for modeling, analyzing phenomena and processes characterized by a large number of characteristics and indicators of enterprise performance. The competitive advantages achieved in this case are ensured through the exchange of resources, information, the formation of development strategies based on supply and demand, additional services, based on the pricing strategy. Clustering is understood as the process of finding groups of objects that have "high" intra-cluster similarity, i.e. objects belonging to one cluster are more similar to each other than to objects belonging to other clusters.

For a small number of factors, characterized by two variables, the results of cluster analysis are represented by dots. The decisive criterion for determining the similarity of features is the distance between the points on the scatterplot. The definition of clusters and the distribution of objects in accordance with them are expressed in the final data model, which is a solution to the clustering problem [2].

Thus, the task of clustering is to divide the studied set of enterprises into groups with similar properties or attributes. For the classification of enterprises, it is better to apply Ward's hierarchical agglomerative clustering method using the Euclidean metric [3].

As a result of cluster analysis, observation groups are formed using predefined variables. Clustering is designed to reveal local condensations of production facilities 


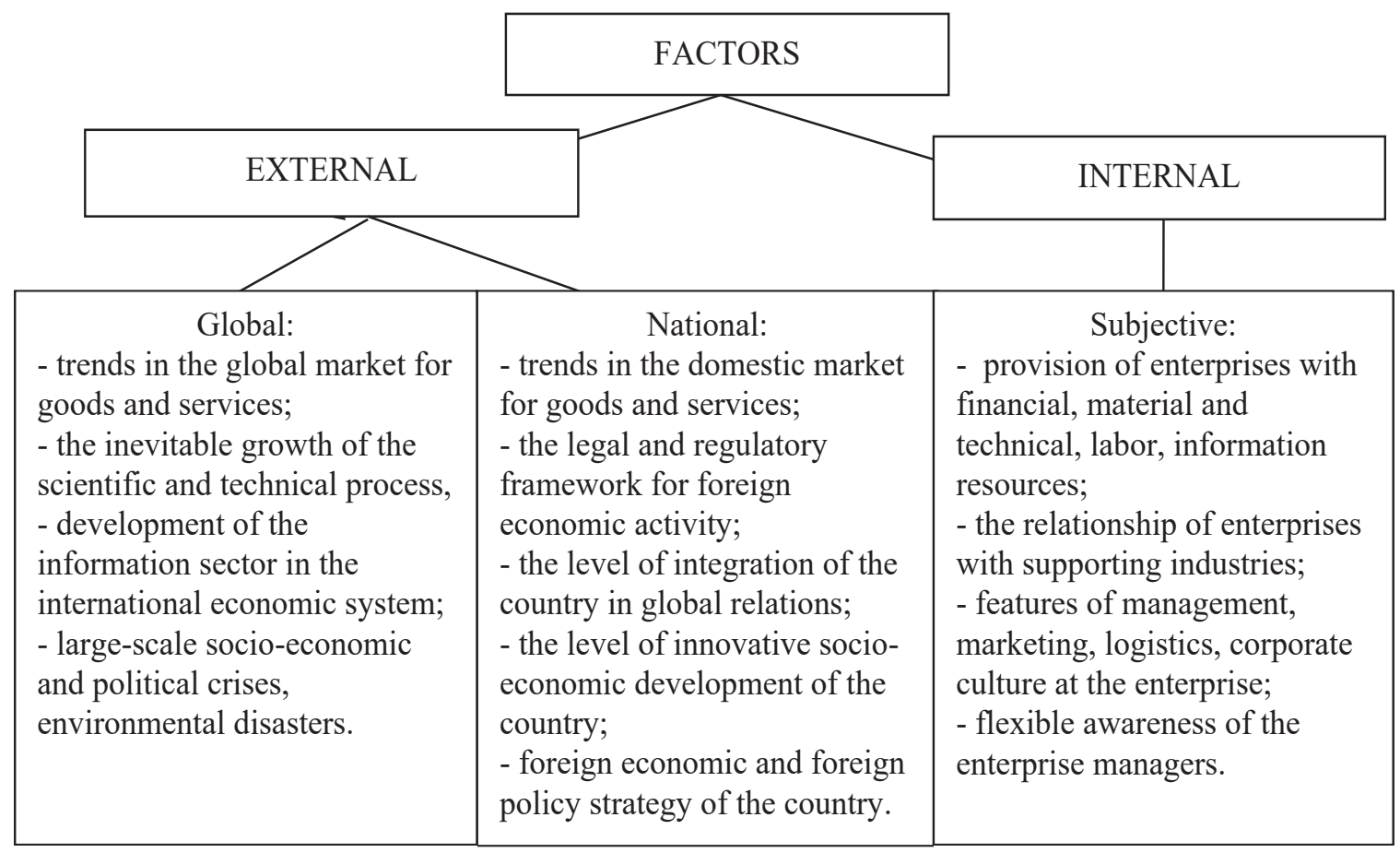

Figure 1 - Factors influencing the management of the business development strategy of the enterprise

behind distinctive features, assuming that the objects are specified in the metric space $\mathrm{X}$ with the metric $\mathrm{p}$. The task of clustering enterprises can be defined as follows: it is necessary to group enterprises into a cluster in such a way that the distance between different clusters is significant, and between objects of the same cluster is small, therefore, it is necessary to minimize [3] the functional $\mathrm{F}$ :

$$
F=\frac{\sum_{i=1}^{n} \sum_{x^{t}, x^{j} \in K_{i}} p\left(x^{t}, x^{j}\right)}{\sum_{1 \leq i \leq j \leq n} d\left(K_{i}, K_{j}\right)} .
$$

A significant advantage of cluster analysis is that it allows the division of objects not by one parameter, but by a whole set of features.

The formal statement of the cluster analysis problem is based on a set of data objects $I$, each of which is represented by a set of attributes. It is necessary to construct sets of clusters $C$ and map the set $F, I=\left\{i_{1}, i_{2}, \ldots, i_{j}, \ldots, i_{n}\right\}$, where $i_{j}$ - the object under study, to the set $C$, i.e. $F: I \rightarrow C$. Mapping, $F$ defines the data model, which is the solution to the clustering problem. In other words, the conditions for the formation of clusters are proximity (similarity, kinship, affinity) of objects.

At the first stage, all objects are divided into groups that are closest to the center. Proximity is determined by the distance to the center and its normative characteristics. As linear measures, the Euclidean distance is used, which is determined from the data of the transport portal. It is assumed that the cluster must always have a nodal point, which is the center of the cluster, the degree of membership of which is equal to one, while the limiting ones are equal to zero.

In the second step, new cluster centers are calculated. They can be defined as the average value of variable objects assigned to the formed groups. This operation is repeated recursively until the centers of the clusters stop changing. In this case, the split will be the last.

Since clustering is performed starting from individual members from the bottom to the top, the agglomerative hierarchical clustering method is used. Thus, in the course of clustering, the clusters are combined, and the number of clusters further decreases.

To implement the algorithm of the structural-logical sequence of operations of hierarchical clustering, it is possible to consider the association of entities that are one of the main manufacturers of products, the provision of services in the market, can ensure the entry of their products into the international market. However, to implement the construction of hierarchical clustering, one should not forget about the technical and economic data of enterprises.

The arithmetic mean distance between enterprises in a city can be determined by summing all the distances between enterprises $x_{i}$, and divided by the total number of enterprises $n$.

$$
\bar{x}=\frac{1}{n} \sum_{i=1}^{n} x_{i}=\frac{1}{n}\left(x_{1}+x_{2}+x_{3}+\ldots+x_{n}\right) .
$$

The generalized characteristic $\bar{x}$ reflects the structure of the location of enterprises. An enterprise with the highest agglomeration order can be included in a cluster. For the transition of the technical and economic state of an enterprise into related enterprises of the first group of the cluster, it is necessary to increase the analyzed characteristics to the values of enterprises of this group of the cluster.

After carrying out the appropriate organizational measures aimed at increasing production efficiency, the result of which will be to improve their characteristics, the clustering operations can be repeated again. 
A close relationship is established between groups of clusters. The mechanism of such a merger is proposed: unprofitable enterprises can overcome the lower limit of profitability with the help of specialization, which helps to increase, for example, the level of labor productivity or reduce the cost of production.

The interaction of enterprises, institutions that make up the cluster forms its external and internal environment. The cluster structure helps to reduce the total costs of research and development of innovations, allows cluster members to consistently carry out innovative activities over a long period [2]. All existing connections are possible between the groups of the cluster due to the introduction of innovations and expanded innovative activities at all enterprises and levels of cluster management.

It is better to determine the economic efficiency of clustering operations using the Pareto efficiency apparatus, an improvement in the general condition due to the growth of one of the indicators, provided that the values of the others remain unchanged. Having built clustering, it is possible to determine how and to what minimum the values of one of the analyzed indicators will be.

Cluster communication is a priority task for many innovative strategies. Naturally, even government bodies often use the ideas of clustering to build business ties, establish cooperation between the sectors of industry and science (project support). Such cluster strategies can resiliently change the set of various tools and approaches to the intensification of the development of the activities of any business entity.

Globalization processes open up perspectives for business, but requires careful planning. A certain number of difficulties can emerge only in receiving countries; foreign companies having experience and resources can eliminate local producers from the market, which inevitably impacts the economy of the state. Economic activity of small local companies becomes economically unreasonable; they just cannot compete as equals with transnational holdings. That is why expansion to international market will be beneficial only for producing countries.

Foreign investment flows (FIF) significantly influence the development of the business inside the country: businesses with foreign capital receive a number of benefits compared to local companies. Additional financial investments stimulate industry growth forcing owners to look for new outlet markets that inevitably leads to issues of organizing export and strengthening international collaboration. For business representatives, expansion to foreign arena often seems to be the only appropriate way to keep and increase economic indices, since the demand for the product starts falling after the saturation of the local market, and in order to support former production rates (or intensify them), market expansion is necessary. This pattern is equally justified in both B2B and B2C sector. Main distinctions in the development of new trade connections consist in marketing strategies designed for large business owners or ordinary consumer respectively [4, p. 592-593].

The global nature of the instability of the economy at the present stage, threats and opportunities it generates require changing the nature of crisis management and the tools for designing and implementation of its strategy. In today's practice of crisis management, the priority is often given to mechanisms and tools for immediate response, which eliminate and mitigate the negative effects of the crisis, but do not create conditions for development.

The features of crisis processes require the use of new tools for the development and implementation of a crisis management strategy that can prevent and mitigate not only the negative effects of the crisis, but also use its capabilities to operate the enterprise after the crisis. Based on the fact that economic crises should be considered as a general pattern inherent in a market economy, any management should be anti-crisis one, that is, it should contain appropriate tools for planning, analyzing, forecasting and controlling in crisis situations [5].

Conclusions. Clustering of enterprises makes it possible to simplify the procedure for diagnosing their strategic confrontation, more precisely to develop strategic, operational and innovative solutions for adapting enterprises to the flexibility of the external environment, development in the context of the European integration.

The use of cluster analysis makes it possible to determine homogeneous groups of enterprises, for each of which unified strategies of economic transformation have been proposed. It is also advisable to apply cluster analysis in trading a segmented market. Thus, the cluster mechanism is more a combination of tools, methods, techniques, concepts, means of exchange of information circulating between the cluster core and the subjects of cluster relations.

The introduction of cluster technologies for combining enterprises contributes to the growth of business activity of entrepreneurial structures, an improvement in the investment climate in the region of the country, the development of economic, information and integration systems, which, in turn, gives impetus for a stronger relationship between the internal and external environment of the enterprise.

\section{References:}

1. Kharchova promislovist of Ukraine: country and perspective / ed. I.R. Yukhnovsky. Kiev: Znannya, 2007. 670 p.

2. Advokatova N.O. Management of the innovation activity of the swollen enterprises in the context of the safety of the good quality of the product. Available at: http://libtomcat.knteu.kiev.ua (accessed 21 September 2020).

3. Denisenko M.P. Innovation Processes in Economic Economy: Monograph. Kiev: IPK DSZU, 2008. 240 p.

4. Boiarchuk A.I., Fomishyna V.N., Ohorodnyk R.P. Predicting plausible threats: impact of globalization patterns on national economies. Journal of Security and Sustainability. Issues: Research Article: 2019 December. Volume 9. № 2. Pp. $585-594$.

5. Stattev V. Formation of a System of Anti-Crisis Entrepreneurship of Services Companies / V. Stattev, A. Boiarchuk, O. Portna, M. Dielini, O. Pylypiak. Journal of Entrepreneurship Education: Research Article: 2019. Volume 22. Issue: 1S (Title Entrepreneurship: Investment and Innovation).

6. Amosha O.I. Activation of innovation activity: organizational legal and social and economic security: monograph / O.I. Amosha, V.P. Antonyuk, A.I. Zemlyankin / Institute of Economics and Industry of the National Academy of Sciences of Ukraine. Donetsk, 2007. 328 p.

7. Garafonova O.I. Formation of the competitive potential of the enterprise on the basis of the motivation for innovation and the implementation of the competition. Social and economic development of regions in the context of international integration: KhNU, 2013. № 12 (1). Volume 1. Pp. 164-167. 
8. Plyaskina A. (2020) The economic essence of the "development strategy" of the enterprise and the factors that affect it. Businessnavigator, no. 3 (59), pp. 114-118.

9. Schumpeter J. A. The theory of economic development [Edited by J. E. Eloit]. New Brunswick, New Jersey: Transaction Publ, 2012. $255 \mathrm{p}$.

10. Rayleigh. Joseph John Thomson. Obituary Notices of Fellows of the Royal Society, 1941. Volume 3. No. 10. Pp. 586-609.

11. Volberda H. W. Building Flexible Organizations for Fast-moving Markets. Long Range Planning. 1997. Volume 30. No. 2. Pp. 169-183.

Пляскіна А.I.
Херсонський національний технічний університет

\section{ФОРМУВАННЯ ДІЛОВОЇ СТРАТЕГІЇ РОЗВИТКУ НА ОСНОВІ МЕХАНІЗМІВ ІНТЕГРОВАНОСТІ ПІДПРИЄМСТВА}

Досліджено та систематизовано наукові підходи щзодо структури та формування ділової стратегї розвитку підприємства у відповідності до його иілей та можливостей. Проаналізовано та обтрунтовано специфіку ділової стратегії розвитку підприємства на основі механізмів інтегрованості. В статті розкрито основні рекомендаиї шодо формування ділової стратегї розвитку підприємства з урахування зовнішніх та внутрішніх факторів. Обгрунтовано головні задачі, які необхідно вирішувати в процесі формування стратегії розвитку підприємства. Доведено, щзо, оскільки сучасні економічні умови є динамічними та невизначеними, то одним із головних факторів, який може покращити стан підприємства на ринку, є активна стратегія розвитку, тобто ділова. Аналіз понять “розвиток” $i$ “стратегія” дозволив виявити змістовні особливості механізму формування стратегї розвитку підприємства. Результати, отримані в проиесі дослідження, які знайшли відображення в иій статті, можуть стати базисом для проведення перспективних наукових досліджень щодо обтрунтування $i$ формалізаиї науково-методичних підходів до формування механізму розробки стратегї розвитку підприємств. Ділова стратегія розвитку підприємства розглядається як активна стратегія, яка трунтується на швидкості дій підприємства на зміну тенденціям зовнішніх процесів суспільства; гнучкості прочесів, які відбуваються на підприємстві; постійному пошуку $i$ запровадженню нововведень у діяльність підприємства. Доведено, щяо підприємства безпосередньо взаємодіють із зовнішнім середовищем, враховуючи тендениії розвитку інтеграчійних проиесів. Розглянуто розвиток підприємства з боку ідентифікуючих ознак його стану. Також автор статті розглядає розвиток підприємства через його стратегічні напрями з урахуванням впливу зовнішнього середовища на підприємства. Для иього було уточнена природа стратегії розвитку підприємства. В подальшому така стратегія повинна базуватися на інтенсивному розвитку підприємства. Результати проведеного дослідження можуть бути використані керівниками підприємств для вибору обтрунтованої стратегії розвитку та посилення конкурентних позицій підприємств на ринку.

Ключові слова: розвиток, розвиток підприємства, ділова стратегія розвитку, трансформація, фактори, інтеграчія. 